\title{
PENGARUH PBL BERBASIS FLIPPED CLASS TERHADAP PRESTASI DITINJAU DARI MOTIVASI BELAJAR SISWA
}

\author{
Wolfharda Fitriani Sinmas ${ }^{1},{ }^{*}$ Chandra Sundaygara ${ }^{2}$, Kurriawan Budi Pranata ${ }^{3}$ \\ Program Studi Pendidikan Fisika, Universitas Kanjuruhan Malang 1, 2,3 \\ e-mail : chandrakirana@unikama.ac.id
}

\begin{abstract}
Abstrak. Kegiatan pembelajaran fisika hendaknya lebih melibatkan siswa secara aktif dalam menyelesaikan permasalahan yang dihadapinya dalam pembelajaran. Untuk memfasilitasinya diperlukan model ataupun metode pembelajaran inovatif, yang berorientasi pada masalah dan bersifat student centered. Salah satu model pembelajaran yang dapat digunakan adalah model pembelajaran PBL dengan metode flipped class. Penelitian ini bertujuan untuk mengetahui pengaruh model pembelajaran PBL berbasis flipped class terhadap prestasi belajar ditinjau dari motivasi belajar siswa. Populasi dalam penelitian ini adalah siswa kelas X SMK Negeri 2 Singosari tahun pelajaran 2018/2019. Sampel diambil dengan teknik purposive sampling. Jenis penelitian yang digunakan adalah quasy eksperimen dengan rancangan penelitian posstest only control grup design. Data dianalisis dengan menggunakan uji ANOVA dua jalur. Hasil penelitian ini menunjukan bahwa (1) ada perbedaan prestasi belajar siswa yang belajar melalui model pembelajaran problem based learning berbasis flipped class dengan siswa yang belajar melalui model pembelajaran konvensional, nilai signifikkansi $0.00<0.05$; (2) ada perbedaan prestasi belajar antara siswa yang memiliki motivasi belajar tinggi dengan siswa yang memiliki motivasi belajar rendah, nilai signifikansi $0.01<0.05$; (3) terdapat interaksi antara model pembelajaran problem based learning berbasis flipped class dengan motivasi terhadap prestasi belajar siswa, nilai $F_{\text {hitung }}>F_{\text {tabel }}(6.24>3.91)$.
\end{abstract}

Kata Kunci : PBL; Flipped Class; Motivasi Belajar; Prestasi

\section{PENDAHULUAN}

Fisika adalah salah satu cabang dari IPA yang pada dasarnya merupakan ilmu pengetahuan tentang gejala alam yang dituangkan berupa fakta, konsep, prinsip, dan hukum yang telah teruji kebenarannya melalui serangkaian kegiatan dalam metode ilmiah. Sebagai cabang IPA, pelajaran fisika tidak terlepas dari cara berpikir dan menyelidiki. Penyelidikan ini bertujuan untuk mencari tahu kebenaran suatu konsep yang sudah ada maupun untuk menemukan aplikasi dari konsep fisika tersebut. Fisika dipandang sebagai suatu mata pelajaran yang sulit, dikarenakan sering mempelajari sesuatu yang abstrak, suasana pembelajaran yang kurang menyenangkan, dan guru lebih mendominasi pembelajaran (Jehanus, Ayu, \& Sundaygara, 2019). Oleh karena itu, pembelajaran fisika hendaknya lebih dapat menciptakan suasana pembelajaran aktif dan menyenangkan bagi siswa. Nurqomariah, dkk (2015) mengatakan bahwa pembelajaran IPA fisika bukan hanya untuk menguasai sejumlah pengetahuan sebagai produk IPA fisika, tetapi juga menyediakan ruang untuk tumbuh dan berkembangnya sikap ilmiah, berlatih melakukan proses pemecahan masalah, dan penerapan IPA fisika dalam kehidupan nyata karena salah satu tujuan dari pembelajaran IPA fisika yaitu siswa diharapkan dapat mengkonstruksi pengetahuannya dalam pikirannya dan bekerja memecahkan masalah agar siswa dapat memahami dan dapat menerapkan pengetahuannya. Hal ini juga sejalan dengan hakekat pembelajaran fisika menurut Naizhela, dkk (2015) yaitu terbentuknya kemampuan bernalar pada siswa yang tercermin melalui kemampuan berfikir logis, sistematis, dan mempunyai sifat objektif, jujur disiplin dalam memecahkan suatu masalah. Sesuai dengan hakekat pembelajaran fisika ini, maka kegiatan pembelajaran fisika hendaknya lebih menekankan pada peran aktif siswa dalam melakukan kegiatan pembelajaran misalnya dengan memecahkan masalah yang mereka temui. Untuk mengatasi permasalahan dalam 
pembelajaran diperlukan model ataupun metode pembelajaran inovatif, dan berorientasi pada masalah yang dapat meciptakan kegiatan pembelajaran yang berpusat pada siswa (student center). PBL merupakan salah satu model pembelajaran inovatif yang dapat digunakan dalam pembelajaran fisika.

PBL adalah model pembelajaran yang merangsang siswa untuk menganalisis masalah, memperkirakan jawabannya, mencari data, menganalisis data dan menyimpulkan jawaban terhadap masalah (Wardhani, Sunarno, \& Suparmi, 2012). PBL mampu melibatkan siswa secara keseluruhan dalam proses pembelajaran sehingga membantu siswa untuk lebih berpikir secara aktif, kreatif, dan bertanggung jawab terhadap tugas yang diberikan untuk menemukan cara pemecahan masalah sehingga mendapatkan hasil yang optimal dan meningkatkan prestasi belajar siswa (Pradnyana, dkk., 2013). Tetapi dalam penerapannya, PBL akan sangat sulit dipelajari jika siswa tidak memiliki pemahaman yang memadai akan permasalahan yang ia hadapi untuk memecahkannya, selain itu PBL membutuhkan waktu yang lebih lama (Tyas, Retnaning, 2017; Sanjaya, 2008; Saleh, Marhamah, 2013). Untuk memfasilitasinya, diperlukan model ataupun metode pembelajaran yang sekiranya bisa menarik serta mendorong siswa untuk belajar secara mandiri guna mengetahui materi pelajaran yang berkaitan dengan permasalahan yang akan dihadapi sehingga siswa akan memiliki gambaran atau pemahaman akan permasalahan yang dihadapinya serta dapat meminimalkan penggunaan waktu pembelajaran.

Salah satu metode pembelajaran yang dapat digunakan untuk melengkapi model PBL ini adalah metode pembelajaran flipped class. Metode pembelajaran flipped class membantu siswa untuk belajar secara mandiri di rumah melalui video pembelajaran yang diberikan oleh guru, sehingga siswa memiliki persiapan ketika menghadapi masalah dalam kegiatan pembelajaran di sekolah. Konsep pembelajaran flipped class adalah ketika pembelajaran yang biasanya dilakukan siswa di kelas dilakukan di rumah, dan pekerjaan rumah yang biasa dikerjakan di rumah dilakukan di sekolah (Bergmann \& Sams, 2012). Model pembelajaran problem based learning berbasis flipped class ini merupakan suatu pembelajaran inovatif yang dapat memberikan kondisi belajar aktif kepada siswa. Model pembelajaran ini melibatkan siswa dalam kegiatan pemecahan masalah yang dihadapi dalam kegiatan pembelajaran dengan menggunakan pengetahuan yang telah dipelajari siswa di rumah melalui video pembelajaran yang diberikan guru.

Selain penggunaan model pembelajaran yang inovativ dalam suatu proses pembelajaran juga sangat dibutuhkan adanya motivasi belajar. Motivasi belajar dapat menarik dan mendorong siswa untuk semakin aktif terlibat dalam kegiatan pembelajaran. Penggunaan model pembelajaran PBL berbasis flipped class diharapkan mampu memberi dampak positif terhadap prestasi belajar ditinjau dari motivasi belajar siswa.

Adapun tujuan dari penelitian ini adalah untuk: 1) mengetahui perbedaan prestasi belajar fisika siswa yang belajar melalui model pembelajaran problem based learning berbasis flipped class dengan siswa yang belajar melalui model pembelajaran konvensional. 2) mengetahui adanya perbedaan prestasi belajar antara siswa yang memiliki motivasi belajar tinggi dengan siswa yang memiliki motivasi belajar rendah. 3) mengetahui interaksi antara model pembelajaran problem based learning berbasis flipped class dengan motivasi terhadap prestasi belajar siswa.

\section{METODE PENELITIAN}

Penelitian ini menggunakan metode penelitian kuantitatif dengan jenis quasy experiment atau eksperimen semu. Desain penelitian yang digunakan adalah posttest only control group design. Penelitian menggunakan dua kelompok yaitu kelompok eksperimen dan kelompok kontrol. Kelompok eksperimen adalah kelompok yang diberi perlakuan menggunakan model pembelajaran problem based learning berbasis flipped class dan kelompok kontrol adalah kelompok yang tidak diberi perlakuan.

Subjek dalam penelitian ini meliputi siswa kelas $\mathrm{X} \mathrm{Rpl}{ }_{1}$ dan siswa kelas $\mathrm{X} \mathrm{Mm}_{2}$ dengan jumlah keseluruhan 68 siswa. Penentuan subjek dilakukan dengan menggunakan teknik purposive sampling yaitu pengambilan sampel dari populasi dengan mempertimbangkan kesetaraan kemampuan awal pada semua populasi. Populasi dalam penelitian ini merupakan seluruh siswa kelas X SMK Negeri 2 Singosari. 
Instrumen pengumpul data dalam penelitian ini adalah tes pilihan ganda yang terdiri dari 20 butir soal untuk mengetahui prestasi belajar dan observasi untuk mengetahui motivasi belajar. Teknik analisis data yang digunakan dalam penelitian ini ada dua macam yaitu uji prasyarat dan uji hipotesis. Uji prasyarat ini berguna untuk mengetahui apakah data untuk pengujian hipotesis dapat dilanjutkan atau tidak, uji prasyarat ini meliputi uji normalitas menggunakan uji lilliefors dan uji homogenitas menggunakan uji bartlet. Setelah dilakukan uji prasyarat maka dilakukan uji hipotesis dengan teknik analisis ANOVA 2 JALUR. Adapun semua analisis yang digunakan dalam penelitian ini menggunakan taraf signifikansi $5 \%$ dan menggunakan Microsoft excel 2010.

\section{HASIL DAN PEMBAHASAN}

Berdasarkan hasil penelitian yang telah dilakukan diperoleh data prestasi belajar siswa pada kelas ekperimen maupun pada kelas kontrol setelah kedua kelas ini mendapat perlakuan yang berbeda. Pada kelas eksperimen diberi perlakuan menggunakan model pembelajaran problem based learning berbasis flipped class dan pada kelas kontrol diberi perlakuan menggunakan model pembelajaran konvensional. Berikut adalah deskripsi data prestasi belajar siswa kelas eksperimen dan kontrol.

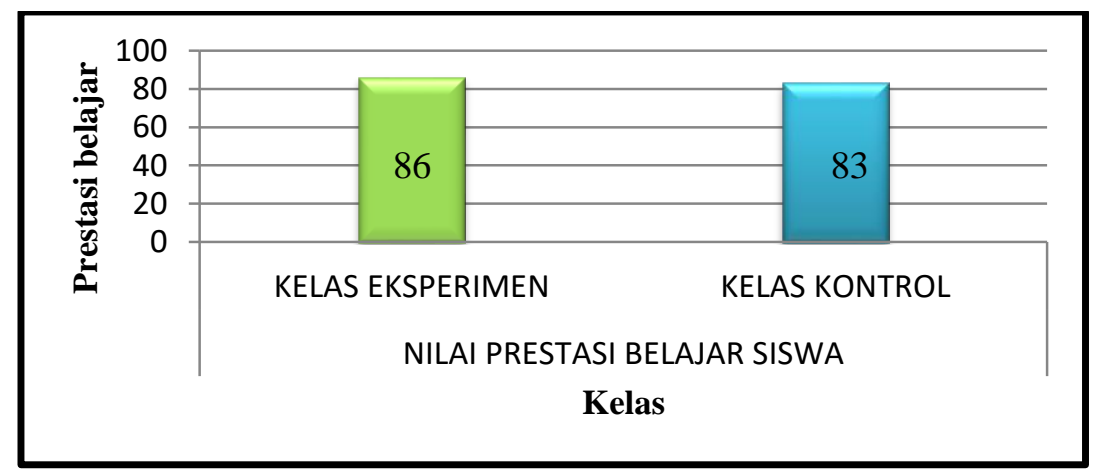

Gambar 1. Prestasi Belajar

Gambar 1 di atas menunjukan bahwa kelas eksperimen memiliki rata-rata nilai prestasi yang lebih tinggi dari pada kelas kontrol. Dimana, rata-rata nilai kelas eksperimen 86 dan kelas kontrol 83. Selanjutnya untuk mengetahui ada tidaknya perbedaan prestasi belajar siswa pada kelas eksperimen dan kontrol dilakukan uji hipotesis menggunakan uji ANOVA 2 jalur. Hasil analisis data menggunakan uji anova 2 jalur dapat dilihat pada tabel berikut.

Tabel 1. Hasil Uji Anova Prestasi Belajar Siswa

\begin{tabular}{ccc}
\hline Sumber Varian & Taraf Signifikansi & Nilai Signifikansi \\
\hline Model pembelajaran * Prestasi belajar & 0.05 & 0.00 \\
\hline
\end{tabular}

Hasil analisis anova 2 jalur pada tabel di atas menunjukan bahwa nilai signifikansi yang diperoleh lebih kecil dari taraf signifikansi yang telah ditetapkan $(0.00<0.05)$. Hal ini berarti bahwa terdapat perbedaan prestasi belajar siswa yang belajar melalui model pembelajaran problem based learning berbasis flipped class dengan siswa yang belajar melalui model pembelajaran konvensional. Penemuan ini konsisten dengan hasil penelitian terdahulu yang menunjukan bahwa pembelajaran berbasis masalah berpengaruh terhadap hasil belajar siswa, pembelajaran berbasis masalah yang diterapkan di kelas eksperimen dapat meningkatkan hasil belajar siswa secara signifikan (Mayasari \& Adawiyah, 2015). Sejalan dengan itu penggunaan metode flipped class juga dapat meningkatkan prestasi belajar siswa. Hasil penelitian yang dilakukan oleh Wulansari \& Sutrisna, 2018 menunjukan bahwa terdapat pengaruh penerapan flipped classroom terhadap hasil belajar mahasiswa.

Model pembelajaran problem based learning berbasis flipped class adalah perpaduan antara model pembelajaran PBL dengan metode flipped class. Model pembelajaran ini memberikan kondisi belajar aktif kepada siswa dengan melibatkan siswa dalam proses pemecahan masalah yang dihadapi dalam kegiatan pembelajaran di kelas menggunakan 
pengetahuan yang telah dipelajarinya di rumah melalui video pembelajaran. PBL adalah suatu model pembelajaran, yang mana siswa sejak awal dihadapkan pada suatu masalah, kemudian diikuti oleh proses pencarian informasi yang bersifat student centered (Suprihatiningrum, 2013). Dalam hal ini metode flipped class dapat mempermudahkan siswa dalam melakukan kegiatan pemecahan masalah dan pencarian informasi karena siswa sudah terlebih dahulu memahami materi-materi atau informasi-informasi yang berkaitan dengan permasalahan yang dihadapinya melalui video pembelajaran yang diberikan. Wulandari \& Surjono, 2014 mengatakan metode flipped class melibatkan partisipasi aktif siswa secara individu untuk mendalami materi pelajaran di luar kelas dengan waktu yang tidak terbatas sebelum pelajaran dimulai, dapat membantu siswa untuk lebih aktif dan mandiri dalam proses belajar dan waktu di dalam kelas digunakan untuk memecahkan masalah yang ditemukan siswa dalam belajar.

Data motivasi belajar dalam penelitian ini dilakukan melalui kegiatan observasi yang dilakukan oleh observer pada kelas eksperimen dan kelas kontrol. Selanjutnya dari hasil observasi diukur pengaruhnya terhadap prestasi dari masing-masing siswa yang memiliki motivasi belajar tinggi dan motivasi belajar rendah dari kedua kelas tersebut. Berikut adalah paparan prestasi belajar siswa pada kelas eksperimen dan kelas kontrol berdasarkan tinggi rendahnya motivasi belajar.

Tabel 2. Deskripsi Data Prestasi berdasarkan Motivasi Belajar

\begin{tabular}{ccc}
\hline Kelas & Motivasi Belajar & Prestasi Belajar \\
\hline \multirow{2}{*}{ Eksperimen } & Tinggi & 95 \\
\cline { 2 - 3 } & Rendah & 71.7 \\
\hline \multirow{2}{*}{ Kontrol } & Tinggi & 94.2 \\
\cline { 2 - 3 } & Rendah & 65.8 \\
\hline
\end{tabular}

Pada tabel 2 di atas dapat diketahui bahwa siswa yang memiliki nilai motivasi belajar tinggi akan memiliki nilai prestasi belajar yang tinggi, sedangkan siswa yang memiliki motivasi belajar rendah memiliki prestasi belajar yang rendah pula. Ada tidaknya pengaruh motivasi belajar terhadap prestasi belajar siswa ini diukur menggunakan uji ANOVA 2 Jalur seperti terlihat pada tabel berikut.

Tabel 3. Hasil Uji Anova Pengaruh Motivasi Belajar terhadap Prestasi Belajar

\begin{tabular}{ccc}
\hline Sumber Varian & Taraf Signifikansi & Nilai Signifikansi \\
\hline Motivasi belajar*prestasi belajar & 0.05 & 0.01 \\
\hline
\end{tabular}

Berdasarkan analisis uji anova 2 jalur pada tabel 3 di atas menunjukan bahwa nilai signifikansi yang didapatkan lebih kecil dari taraf signifikansi yang ditetapkan dalam penelitian ini $(0.01<0.05)$. Hal ini berarti ada perbedaan prestasi belajar siswa yang memiliki motivasi belajar tinggi dengan siswa yang memiliki motivasi belajar rendah. Hasil penelitian penelitian ini sejalan dengan penelitian terdahulu yang menunjukan bahwa terdapat pengaruh yang signifikan antara motivasi dan prestasi belajar (Ghulam \& Hamdu, 2011; Daud Firdaus, 2012; Inayah, dkk., 2013; Saleh Minhayati, 2014).

Motivasi belajar sangat erat kaitannya dengan prestasi belajar, motivasi belajar yang tinggi akan menghasilkan prestasi belajar yang tinggi, begitupun sebaliknya motivasi belajar yang rendah akan menghasilkan prestasi belajar yang rendah pula. Palupi, dkk., 2014 mengatakan bahwa dalam kegiatan belajar motivasi sangat diperlukan, sebab seseorang yang tidak mempunyai motivasi dalam belajar, tidak akan mungkin melakukan aktifitas belajar. Motivasi akan membangkitkan semangat belajar. Inayah, dkk., 2013 dalam penelitiannya menggatakan ada pengaruh langsung positif motivasi belajar siswa terhadap prestasi belajar. Siswa yang memiliki motivasi belajar tinggi akan cenderung memiliki prestasi belajar yang tinggi pula, sedangkan siswa yang memiliki motivasi belajar rendah cenderung memiliki prestasi belajar yang rendah. Dengan demikian, motivasi belajar sangatlah penting dalam meningkatkan prestasi belajar.

Dari hasil analisis hipotesis pertama dan kedua yang telah dipaparkan di atas dapat diketahui bahwa model pembelajaran problem based learning berbasis flipped class berpengaruh terhadap prestasi belajar siswa, demikian pula motivasi belajar berpengaruh 
terhadap prestasi belajar siswa. Oleh karena itu, penelitian ini juga menguji apakah ada interaksi antara model pembelajaran problem based learning berbasis flipped class dan motivasi belajar terhadap prestasi belajar. Hasil analisis interaksi disajikan pada tabel berikut.

Tabel 4. Hasil Analisis Interaksi

\begin{tabular}{lcc}
\hline Sumber Varian & $\mathbf{F}_{\text {hitung }}$ & $\mathbf{F}_{\text {tabel }}$ \\
\hline Interaksi & 6.24 & 3.91 \\
\hline
\end{tabular}

Hasil analisis interaksi pada tabel 4 di atas menunjukan bahwa terdapar interaksi antara model pembelajaran problem based learning berbasis flipped class dengan motivasi belajar terhadap prestasi belajar siswa. Hal ini ditunjukan dengan hasil uji anova 2 jalur yang menunjukan nilai $\mathrm{F}_{\text {hitung }}>\mathrm{F}_{\text {tabel }}(6.24>3.91)$, artinya bahwa ada pengaruh interaksi antara model pembelajaran problem based learning berbasis flipped class dengan motivasi belajar terhadap prestasi belajar siswa.

Model pembelajaran problem based learning berbasis flipped class yang digunakan dalam penelitian ini menciptakan kegiatan pembelajaran yang berpusat pada siswa dengan berbasiskan masalah, sehingga siswa dituntut untuk lebih aktif dalam mencari solusi dari permasalahan yang dihadapi. Model pembelajaran ini menuntut siswa untuk belajar secara mandiri di luar kelas melalui video pembelajaran yang disediakan oleh guru. Melalui video pembelajaran siswa mengasah kemampuan mengingat dan memahami materi yang disajikan. Kegiatan pembelajaran dalam kelas akan melibatkan kemampuan tingkat tinggi siswa dengan menggunakan langkah - langkah model pembelajaran PBL dalam menyelesaikan masalah yang dihadapinya. Dalam menyelesaikan permasalahan yang dihadapi, siswa akan lebih bersemangat karena sudah memiliki pengetahuan tentang materi yang berkaitan dengan permasalahan tersebut melalui video pembelajaran yang telah dipelajarinya di rumah. Ketika siswa bersemangat dalam pembelajaran maka siswa akan termotivasi untuk melakukan kegiatan pembelajaran dengan sungguh - sungguh, sehingga ia akan berusaha lebih giat dan intens dalam belajar untuk lebih memahami apa yang dipelajari, sehingga prestasi belajar yang baik dan optimal dapat tercapai.

Selain model pembelajaran motivasi belajar juga sangat diperlukan dalam kegiatan pembelajaran. Prestasi belajar yang dicapai seseorang ditentukan oleh potensi dan motivasi yang dimiliki orang tersebut, tetapi betapapun tinggi potensi seseorang jika memiliki motivasi yang rendah maka prestasi yang dicapai juga akan rendah (Saleh M., 2014). Dengan demikiian motivasi belajar dan prestasi belajar memiliki hubungan yang sangat tinggi. Inayah, dkk., 2013 mengatakan bahwa jika ada motivasi belajar yang tinggi maka akan ada prestasi belajar yang tinggi pula. Dengan demikian, model pembelajaran problem based learning berbasis flipped class dengan motivasi belajar dapat mengoptimalkan prestasi belajar siswa.

\section{KESIMPULAN}

Bedasarkan hasil penelitian dan pembahasan tentang pengaruh model pembelajaran problem based learning berbasis flipped class terhadap prestasi belajar ditinjau dari motivasi belajar siswa, maka dapat disimpulkan sebagai berikut:

1. Ada perbedaan prestasi belajar antara siswa yang belajar melalui model pembelajaran problem based learning berbasis flipped class dengan siswa yang belajar melalui model pembelajaran konvensional.

2. Ada perbedaan prestasi belajar antara siswa yang memiliki motivasi belajar tinggi dengan siswa yang memiliki motivasi belajar rendah.

3. Ada interaksi antara model pembelajaran problem based learning berbasis flipped class dengan motivasi belajar terhadap prestasi belajar sisiwa. 


\section{SARAN} yaitu:

Berdasarkan hasil akhir dari penelitian ini, maka peneliti memiliki beberapa saran,

1. Sekolah dapat mempertimbangkan hasil penelitian ini untuk diterapkan guna menciptakan kegiatan pembelajaran inovatif dan menyenangkan untuk memotivasi siswa dan meningkatkan prestasi belajar siswa.

2. Guru dapat menggunakan model pembelajaran problem based learning berbasis flipped class ini sebagai alternative model pembelajaran di kelas.

3. Bagi peneliti selanjutnya dapat melakukan penelitian menggunakan model pembelajaran ini yang ditinjau dari kemandirian belajar, selain itu dapat menggunakan model pembelajaran ini untuk materi-materi pembelajaran yang lain.

\section{DAFTAR RUJUKAN}

Bergmann, J., \& Sams, A. (2012). Flip Your Classroom: Reach Every Student in Every Class Every Day. Washington DC: International Society for Technology in Education.

Daud, F. (2012). Pengaruh Kecerdasan Emosional (EQ) dan Motivasi Belajar terhadap Hasil Belajar Biologi Siswa SMA 3 Negeri Kota Palopo. Jurnal Pendidikan dan Pembelajaran, 19 (2). 243 - 255.

Hamdu, G., \& Agustina, L. (2011). Pengaruh Motivasi Belajar Siswa terhadap Prestasi Belajar IPA di Sekolah Dasar. Jurnal Penelitian Pendidikan, 12 (1). 90 - 96.

Inayah, R., \& dkk. (2013). Pengaruh Kompetensi Guru, Motivasi Belajar Siswa, dan Fasilitas Belajar terhadap Prestasi Belajar Mata Pelajaran Ekonomi Pada Siswa Kelas XI IPS SMA Negeri 1 Lasem Jawa Tengah. Jurnal Pendidikan Mandiri, 1 (1). 4 - 7.

Jehanus, R. C., Ayu, H. D., \& Sundaygara, C. (2019). Pengaruh Problem Based Learning berbasis Asesmen Kinerja terhadap Penguasaan Konsep Fisika ditinjau dari Kerja Ilmiah. Jurnal Pendidikan Fisika Universitas Muhammadiyah Metro, 39-45.

Mayasari, R., \& Adawiyah, R. (2015). Pengaruh Model Pembelajaran Biologi terhadap Hasil Belajar dan Keterampilan Berpikir Tingkat Tinggi di SMA. Jurnal Pendidikan Biologi Indonesia, 1 (3). 255 - 262.

Naizhela, A. M., \& dkk. (2015). Meningkatkan Hasil Belajar Melalui Pendekatan Kontekstual dengan Metode Think Pair Share Materi Kalor Pada Siswa SMP. Unnes Physics Education Jounal (UPEJ), 4 (1).

Nurqomariah, Gunawan, \& Sutrio. (2015). Pengaruh Model Problem Based Learning dengan Metode Eksperimen Terhadap Hasil Belajar IPA Fisika Siswa Kelas VII SMP Negeri 19 Mataram. Program Studi Pendidikan Fisika FKIP, Universitas Mataram. Jurnam Pendidikan Fisika dan Teknologi, I (1).173 - 178.

Palupi, R., Anitah, S., \& Budiyono. (2014). Hubungan antara Motivasi Belajar dan Persepsi Siswa terhadap Kinerja Guru dalam Mengelola Kegiatan Belajar dengan Hasil Belajar IPA Siswa Kelas VIII di SMPN 1 Pacitan. Jurnal Teknologi Pendidikan dan Pembelajaran, 2 (2), 157 - 169.

Pradnyana, P., Marhaeni, \& dkk. (2013). Pengaruh Pembelajaran Berbasis Masalah terhadap Motivasi Belajar dan Prestasi Belajar Matematika Siswa Kelas IV SD. Program Studi Pendidikan Dasar, Program Pascasarjana Universitas Pendidikan Ganesha Singaraja, Indonesia. e-Journal Program Pascasarjana Universitas Pendidikan Ganesha Jurusan Pendidikan Dasar, 3.

Saleh, M. (2013). Strategi Pembelajaran Fiqh dengan Problem-Based Learning. Dosen Fakultas Ilmu Tarbiyah dan Keguruan UIN Syarif Hidayatullah Jakarta. Jurnal Ilmiah DIDAKTIKA, XIV (1). 190-220.

Saleh, M. (2014). Pengaruh Motivasi, Faktor Keluarga, Lingkungan Kampus dan Aktif Berorganisasi terhadap Prestasi Akademik. Jurnal PHENOMENON, 4 (2). 109 - 141.

Sanjaya, W. (2008). Perencanaan dan Desain "Sistem Perencanaan". Bandung: Kencana, Prenadamedia Group.

Suprihatiningrum, J. (2013). Strategi Pembelajaran Teori dan Aplikasi. Jogjakarta: Ar-Ruzz Media. 
Tyas, R. (2017). Kesulitan Penerapan Problem Based Learning dalam Pembelajaran Matematika. Program Studi Akuntansi Universitas Kahuripan Kediri. Tecnoscienza, 2 (1). 43 - 52.

Wardhani, K., Sunarno, W., \& Suparmi. (2012). Pembelajaran Fisika dengan Model Problem Based Learning menggunakan Multimedia dan Modul ditinjau dari Kemampuan Berpikir Abstrak dan Kemampuan Verbal Siswa . Jurnal Inkuiri, 1 (2), 163-168.

Wulandari, B., \& Surjono, D. H. (2013). Pengaruh Problem Based Learning terhadap Hasil Belajar ditinjau dari Motivasi Belajar PLC di SMK. Jurnal Pendidikan Vokasi, 3 (2). $178-191$.

Wulansari, T. N., \& Sutrisna, G. P. (2018). Pengaruh Penerapan Model Pembelajaran Flipped Classroom terhadap Hasil Belajar Kognitif Mahasiswa Keperawatan dalam Materi Ajar Mikrobiologi. Jurnal Bioeducation, 5 (2). 48 - 52. 